\title{
Hydrologic Response to Mechanical Shredding in a Juniper Woodland
}

\author{
Nathan L. Cline, ${ }^{1}$ Bruce A. Roundy, ${ }^{2}$ Fredrick B. Pierson, ${ }^{3}$ Patrick Kormos, ${ }^{4}$ and C. Jason Williams ${ }^{5}$ \\ Authors are ${ }^{1}$ Graduate Research Assistant and ${ }^{2}$ Professor, Department of Plant and Wildlife Sciences, Brigham Young University, Provo, UT 84602, USA; \\ and ${ }^{3}$ Research Leader-Supervisory Research Hydrologist, ${ }^{4}$ Hydrologic Technician, and ${ }^{5}$ Hydrologist, Northwest Watershed Research Center, US \\ Department of Agriculture-Agricultural Research Service, Boise, ID 83712, USA.
}

\begin{abstract}
We investigated soil compaction and hydrologic responses from mechanically shredding Utah juniper (Juniperus ostesperma [Torr.] Little) to control fuels in a sagebrush/bunchgrass plant community (Artemisia nova A. Nelson, Artemisia tridentata Nutt. subsp. wyomingensis Beetle \& Young/Psendoroegneria spicata [Pursh] A. Löve, Poa secunda J. Presl) on a gravelly loam soil with a $15 \%$ slope in the Onaqui Mountains of Utah. Rain simulations were applied on $0.5-\mathrm{m}^{2}$ runoff plots at $64 \mathrm{~mm} \cdot \mathrm{h}^{-1}$ (dry run: soil initially dry) and $102 \mathrm{~mm} \cdot \mathrm{h}^{-1}$ (wet run: soil initially wet). Runoff and sediment were collected from runoff plots placed in five blocks, each containing four microsites (juniper mound, shrub mound, vegetation-free or bare interspace, and grass interspace) with undisturbed or tracked treatments for each microsite type and a residue-covered treatment for grass and bare interspace microsites. Soil penetration resistance was measured at the hill slope scale, and canopy and ground cover were measured at the hill slope and runoff plot scale. Although shredding trees at a density of 453 trees $\cdot \mathrm{ha}^{-1}$ reduced perennial foliar cover by $20.5 \%$, shredded tree residue covered $40 \%$ of the ground surface and reduced non-foliar-covered bare ground and rock by $17 \%$. Tire tracks from the shredding operation covered $15 \%$ of the hill slope and increased penetration resistance. For the wet run, infiltration rates of grass interspaces were significantly decreased $\left(39.8 \mathrm{vs} .66 .1 \mathrm{~mm} \cdot \mathrm{h}^{-1}\right)$ by tire tracks, but infiltration rates on juniper mounds and bare interspaces were unchanged. Bare interspace plots covered with residue had significantly higher infiltration rates $\left(81.9\right.$ vs. $\left.26.7 \mathrm{~mm} \cdot \mathrm{h}^{-1}\right)$ and lower sediment yields $\left(38.6 \mathrm{vs.} 313 \mathrm{~g} \cdot \mathrm{m}^{-2}\right)$ than those without residue. Because hydrologic responses to treatments are site- and scale-dependent, determination of shredding effects on other sites and at hill slope or larger scales will best guide management actions.
\end{abstract}

\section{Resumen}

Se investigó la compactación del suelo y las respuestas hidrológicas generadas por la trituración mecánica de Juniperus osteosperma (Torr.) Little realizada para controlar biomasa combustible en una comunidad arbustivo-graminosa de Artemisia nova A. Nelson, Artemisia tridentata Nutt. subsp. wyomingensis Beetle \& Young/Psendoroegneria spicata [Pursh] A. Löve, y Poa secunda J. Presl en un sitio franco-pedregoso con un $15 \%$ de pendiente en las montañas de Onaqui en Utah. Se utilizaron simuladores de lluvia en parcelas de escurrimiento de $0.5 \mathrm{~m}^{2}$ a razón de $64 \mathrm{~mm} \cdot \mathrm{h}^{-1}$ (simulación en seco: el suelo inicialmente seco) y $102 \mathrm{~mm} \cdot \mathrm{h}^{-1}$ (simulación húmeda: el suelo inicialmente húmedo). Se recolectó el agua de escurrimiento y el sedimento de las parcelas de escurrimiento ubicadas en cinco bloques cada uno de los cuales contenía cuatro micrositios (montículo de Juniperus, montículo de arbustos, espacios entre montículos sin vegetación o con suelo desnudo, y espacios entre pastos) con tratamientos sin disturbio o con huellas de trituradora para cada tipo de micrositio y un tratamiento de cobertura de residuos de espacios de suelo desnudo. La resistencia del suelo a la penetración se midió a la escala de ladera de montaña y la cobertura de canopeo y del suelo se midió a escala de ladera de montaña y de parcela. Si bien la trituración de árboles con una densidad de 453 plantas $\cdot$ ha $^{-1}$ redujo la cobertura foliar perenne en un $20.5 \%$, el residuo de trituración cubrió un $40 \%$ de la superficie del suelo y redujo el suelo desnudo y roca en un $17 \%$. Las huellas de la trituradora cubrieron un $15 \%$ de la ladera de montaña e incrementaron la resistencia a la penetración. Para las simulaciones de lluvia con suelos húmedos, la infiltración de espacios entre pastos decreció significativamente ( 39.8 vs. $66.1 \mathrm{~mm} \cdot \mathrm{h}^{-1}$ ) debido a las huellas de las cubiertas de la trituradora, pero las tasas de infiltración sobre montículos de Juniperus y en espacios de suelo desnudo no presentaron cambios. Los espacios entre montículos con suelo desnudo cubiertos con residuo tuvieron tasas de infiltración significativamente más altas $\left(81.9\right.$ vs. $\left.26.7 \mathrm{~mm} \cdot \mathrm{h}^{-1}\right)$ y producción de sedimentos más baja que aquellos sin residuos. Dado que las respuestas hidrológicas a los tratamientos son sitio- y escala-dependientes, la determinación del efecto de triturado en otros sitios y otras laderas o a escalas superiores deberían guiar las acciones de manejo.

Key Words: compaction, erosion, fuel control, infiltration, mastication, mulch

\section{INTRODUCTION}

This is Contribution 21 of the Sagebrush Steppe Treatment Evaluation Project (SageSTEP), funded by the United States Joint Fire Science Program.

Correspondence: Bruce A. Roundy, Dept of Plant and Wildlife Sciences, Brigham Young University, 275 WIDB, Provo, UT 84602, USA. Email: bruce_roundy@byu.edu

Manuscript received 21 December 2009; manuscript accepted 30 January 2010.
Pinyon (Pinus L. spp.) and juniper (Juniperus L. spp.) woodlands have expanded into sagebrush (Artemisia L. spp.) steppe ecosystems over the last $130 \mathrm{yr}$ and now occupy approximately 20-30 million ha in the western United States (Miller and Wigand 1994; Miller and Tausch 2002). A reduction in fine fuels and fire suppression have facilitated this 
expansion (Miller and Wigand 1994; Miller and Tausch 2002). Juniper expansion and fuel buildup in former sagebrush steppe communities can result in catastrophic fire followed by cheatgrass invasion and dominance (Stringham et al. 2003; Miller et al. 2008; Tausch et al. 2009). Once this biotic threshold is passed, ecosystem processes are altered (D'Antonio and Vitousek 1992) and habitat support for sagebrush obligates can be lost (Wisdom et al. 2005). This process has contributed to the current status of the sagebrush biome as one of the most endangered in the United States (Noss et al. 1995). Runoff and soil erosion may increase with woodland expansion as rills form and coalesce in bare interspaces, especially on sites with steep slopes, erodible soils, and high-intensity thundershowers (Roundy and Vernon 1999; Petersen and Stringham 2008). To avoid these consequences, range managers reduce trees by methods such as fire, chaining, felling, and crushing to reduce fuels and improve ecological function. Such efforts are meant to restore the natural disturbance regime that limited tree expansion in the past. These methods have varying effects on vegetation and surface hydrology (Williamson and Currier 1971; Roundy et al. 1978; Busby and Gifford 1981; Bates et al. 2000; Baker and Shinneman 2004). Currently, both prescribed fire and manual cutting are most frequently used for juniper control, while chaining is much more limited than in the past. Hydrologic impacts of chaining have often been measured at the patch or intercanopy scale, but it is incorrect to assume that these responses scale up linearly to the hill slope or watershed (Roundy and Vernon 1999; Wilcox et al. 2003). Research on the effects of juniper control on hydrologic responses at these larger scales is limited. Treatments such as cut-and-drop that potentially increase ground cover beyond the tree mound and intercept rills would be expected to increase infiltration and reduce erosion.

Recently, mechanical shredding or mastication has become a popular method to control trees because it avoids the risks associated with prescribed fire, and the resulting mulch residue is thought to protect soils from erosion (Fig. 1A). Because Utah juniper (Juniperus ostesperma [Torr.] Little) does not resprout from the roots, shredding trees below lower branch buds effectively sets back woodland expansion for many years until new trees potentially establish from seed dispersal (Chambers et al. 1999). Shredding vehicles maneuver on large rubber tires or steel tracks and shred selected trees with a rotating toothed drum (Bull Hog or similar device), distributing the mulch residue on or immediately around tree mounds. The mulch residue ranges in size from small chips $(\sim 1 \mathrm{~cm}$ in width and length by $<0.5 \mathrm{~cm}$ thick) to twigs and branches, depending on how thorough the operator is and how many teeth are left on the rotating drum. The volume of material is dependent on the size of the tree, with its depth ranging from the thickness of one chip to $>20 \mathrm{~cm}$ deep. The residue may spread from covering only a portion of the tree mound to over $10 \%$ of the area surrounding the mound. The process results in a distribution of mulch residue in place of trees, potential surface compaction, and some surface soil disturbance from vehicle tracks. Between 2004 and 2006, more than 9700 ha of woodland had been shredded in Utah, and future use is expected to increase (B. Washa, personal communication, September 2008). Ecological effects of shredding juniper trees have not been well documented but may include changes in fuel structure that affect

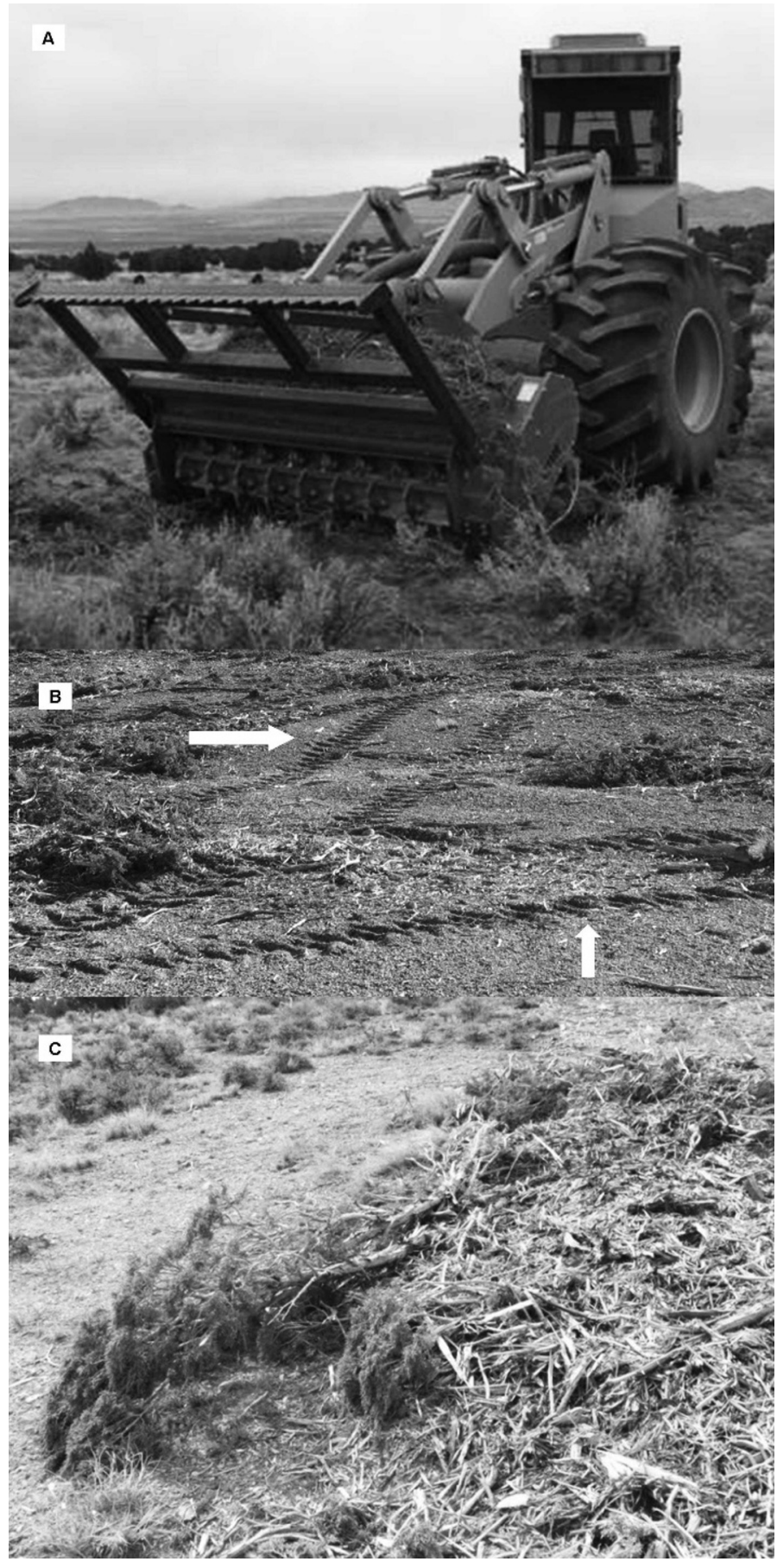

Figure 1. Tigercat M726E Mulcher (A), tire tracks (B), and Utah juniper (Juniperus ostesperma [Torr.] Little) mulch residue (C) at Onaqui Mountains, Utah.

characteristics and impacts of wild or prescribed fire, changes in soil carbon/nitrogen ratios as above- and below-ground tree biomass decomposes, changes in soil moisture and temperature that may benefit desirable understory species or invasive weeds (Benson 2006; Neal 2007), and potentially beneficial hydrologic responses such as increased infiltration and decreased erosion associated with residue coverage of previously bare interspaces.

Researchers have measured the effects of compaction on infiltration rates, soil structure, plant cover, and sediment 
yields. Penetration resistance (which is commonly used to indicate degree of soil compaction) is highly correlated with infiltration rates in agricultural pastures (Haan et al. 2006). Compaction forces reduce soil aggregate strength by breaking down soil structure and disrupting soil porosity (Bruand and Cousin 1995; Sveistrup and Haraldsen 1997), which in turn reduces infiltration rates (Hamlett et al. 1990). Mechanical shredding could trample plants and reduce vegetation cover, which could increase sediment load (Linse et al. 2001; Pierson et al. 2001; Pierson et al. 2002; Haan et al. 2006; Pierson et al. 2008; Pierson et al. 2009). At least five factors affect the degree of soil compaction from vehicular travel: weight of the load, degree of soil disturbance from the travel and operation of the vehicle, soil water content at the time of compaction, number of passes, and compactability of the soil as a function of soil texture (Raper 2005). Shredding vehicles may weigh approximately $16000 \mathrm{~kg}$ (R. Pentesco, personal communication, January 2007), substantially less than a $49000-\mathrm{kg}$ crawler tractor used to pull an anchor chain or push over trees for juniper control.

Mulch residues affect surface hydrology by protecting exposed soil. Covering soils with organic matter, such as mulch, has generally been accepted as a method of decreasing runoff and sediment yields in agricultural soils and may have similar effects in juniper woodlands. In agricultural soils, these coverings are often straw or grasses (Zuzel and Pikul 1993; Blanco-Canqui and Lal 2007). In conifer forest, soils covered with pine (Pinus spp.) mulch had similar sediment yields as grass microsites (Grismer and Hogan 2005). Wood and Javed (1992) showed that leaving slash on a hill slope reduced runoff and sediment in a pinyon (Pinus edulis Engelm.)-juniper (Juniperus deppeana Steud.) woodland.

No research has been reported on soil and hydrologic effects of mechanical shredding in juniper woodlands. The objectives of this study were to quantify soil compaction and hydrological responses to vehicle tracking and mulch residue from mechanical shredding in a Utah juniper (J. osteosperma [Torr.] Little) woodland in central Utah. We hypothesized that at the microsite scale, tracks from a shredding vehicle would increase soil compaction, runoff, and sediment yields and decrease infiltration rates, while shredded residue cover would have the opposite effect.

\section{METHODS AND MATERIALS}

\section{Study Site}

The study was conducted $76 \mathrm{~km}$ southwest of Salt Lake City, Utah, on the eastern slopes of the Onaqui Mountain range (lat $40^{\circ} 12^{\prime} 46^{\prime \prime} \mathrm{N}$, long $\left.112^{\circ} 28^{\prime} 17^{\prime \prime} \mathrm{W}\right)$. The study site is a $0.5-\mathrm{km}-$ long section of a north-facing hill slope and has a slope of $15 \%$. Elevation ranges from $1720 \mathrm{~m}$ to $1738 \mathrm{~m}$. The mean annual temperature is $7.5^{\circ} \mathrm{C}$ with cold winters and hot summers. Annual precipitation is approximately $349 \mathrm{~mm}$ (PRISM Group 2009), most of which falls between October and May. Precipitation intensity for a 10 -yr frequency at the nearby Benmore, Utah, meteorological station is 78 and $33 \mathrm{~mm} \cdot \mathrm{h}^{-1}$ for 5-min and 30-min durations (National Oceanic and Atmospheric Administration 2009). The $1500-\mathrm{m}^{2}$ study area has been excluded from livestock grazing since autumn 2005. The dominant soil type is Borvant gravelly loam series of loamy-skeletal, carbonatic, mesic, shallow Aridic Petrocalcic Palexerolls (United States Department of Agriculture, Natural Resources Conservation Service 2007). The plant community consists of Utah juniper, black sagebrush (Artemisia nova A. Nelson), Wyoming big sagebrush (Artemisia tridentata Nutt. subsp. wyomingensis Beetle \& Young), bluebunch wheatgrass (Pseudoroegneria spicata [Pursh] A. Löve), Sandburg bluegrass (Poa secunda J. Presl), cheatgrass (Bromus tectorum L.), bur buttercup (Ceratocephala testiculata [Crantz] Roth), ballhead ipomopsis (Ipomopsis congesta [Hook.] V.E. Grant), and pale madwort (Alyssum alyssoides L.).

\section{Experimental Design}

The experiment was a randomized block design with five blocks, each approximately $100 \mathrm{~m}^{2}$ in area and each containing four microsite types (juniper mound, shrub mound, grass interspace, and vegetation-free or bare interspace). Within each block and for each microsite type, undisturbed and tracked treatments were measured, and an additional residue-covered treatment was measured for grass and bare interspace microsite types (Figs. 1B and 1C). Runoff plots were placed on each treatment for each microsite and consisted of $0.5-\mathrm{m}^{2}$ galvanized steel frames with a lip to allow runoff to be caught on the downslope end. The frames were pounded into the soil, and disturbed soils on the borders of the frame were refilled with soil adjacent to the plot. In comparisons with tracked plots, undisturbed plots are referred to as untracked plots; when compared with mulch residue plots, undisturbed plots are referred to as withoutresidue plots. As part of a larger study, the undisturbed plots were installed in spring of 2006 and received simulated rainfall during the summer of 2006. Trees were mechanically shredded using a Tigercat M726E Mulcher (Paris, Ontario, Canada) rubber-tired vehicle (Fig. 1A) in fall 2006. The tractor operator was asked to avoid disturbing previously installed plots, which were marked by florescent paint on the plot frame. Two plots were disturbed and made unusable, which resulted in two additional control plots installed in spring 2007. Tracked and residue plots were installed in spring 2007.

\section{Rainfall Simulation}

A Meyer and Harmon (1979) rainfall simulator applied two rainfall events on each runoff plot for all three treatments in late spring 2007. We utilized a Veejet 80-100 nozzle (Veejet, Wheaton, IL) to approximate the kinetic energy of a convective thunderstorm (Meyer and Harmon 1979). The two successive simulations, approximately $30 \mathrm{~min}$ apart, were applied at $64 \mathrm{~mm} \cdot \mathrm{h}^{-1}$ (dry run: soil initially dry) and $102 \mathrm{~mm} \cdot \mathrm{h}^{-1}$ (wet run: soil initially wet) for $45 \mathrm{~min}$ each. These rates were selected to achieve a steady state infiltration rate. Timed samples of surface water runoff were collected from each plot at 1-2-min intervals during rainfall simulation. Each sample was weighed, dried $\left(105^{\circ} \mathrm{C}\right)$, and weighed again to obtain runoff volume and sediment mass. Variables derived from runoff and sediment measurements included final infiltration rate (used as the steady state value), minimal infiltration rate (the lowest infiltration rate during the simulations), time to the start of runoff, time to peak runoff (highest measured runoff rate), cumulative runoff (total runoff during simulation), runoff/rainfall ratio, cumulative sediment (total sediment 
during simulation), and runoff/sediment ratio. Infiltration rate was calculated as the difference between applied rainfall and measured runoff and therefore includes surface storage and rainfall interception.

\section{Soil and Vegetation}

We measured tree, understory vegetation, and ground cover at the hill slope scale using three $30 \times 33 \mathrm{~m}$ randomly placed macroplots. In these macroplots, we measured understory vegetation and ground cover both before and after shredding by the line-point method (Mueller-Dombois and Ellenberg 1974) at 60 points on each of five $30-\mathrm{m}$ transects per macroplot. All foliar and surface hits were recorded. Trees were tallied and tree canopy cover was calculated prior to shredding by the crown-diameter method (Mueller-Dombois and Ellenberg 1974). After shredding, we measured the cover of tire tracks on the study site using the line-intercept method on five 30-m transects per macroplot. We used a cone penetrometer (FieldScout SC-900 Soil Compaction Meter; FieldScout, Plainfield, IL) to measure soil resistance of tracked and untracked soils in October 2007, 1 yr after shredding. Measurements were recorded along both an upslope and downslope transect placed perpendicular to the slope, stretching across the entire study site, and spaced $12 \mathrm{~m}$ apart. At each of the four microsites closest to seven (upslope transect) or eight (downslope transect) points, penetration resistance was measured by pressing the top of the penetrometer cone to depths of $0 \mathrm{~cm}, 2.5 \mathrm{~cm}, 5 \mathrm{~cm}, 7.5 \mathrm{~cm}$, and $10 \mathrm{~cm}$ for both tracked and untracked microsites. Litter was left in place on juniper mounds during these measurements.

We also measured canopy and ground cover, surface roughness (microtopographic variation), and soil water content at each runoff plot before rainfall simulation began. Canopy, ground cover, and surface roughness were measured using the point frame method at 15 measurement points along seven transects (105 points). Surface roughness was measured and derived as described by Pierson et al. (2007b). Vegetation and ground cover was differentiated into biologic crust, mosses, grasses, forbs, shrubs, tree mulch residue, bare ground, litter, rock ( $\geq 5 \mathrm{~mm}$ ), and standing dead. Soil samples $(0-5 \mathrm{~cm})$ were collected next to each runoff plot (total of 50) at the time of simulation and analyzed for gravimetric soil water content.

\section{Data Analysis}

Cover averages were calculated across all macroplot transects to characterize hill slope tree and understory cover, mulch distribution, and ground cover before and after treatment. Resistance to penetration was analyzed across the hill slope using depth as a repeated measure, microsite and tracking as fixed factors, and sample point as random in a mixed model analysis (Littell et al. 1996). Mixed model analysis was also used to determine fixed effects of microsite and tracking on hydrologic and other responses measured at the runoff-plot scale, with block considered random. The arcsin square root transformation was performed to normalize data for time to runoff, time-to-peak runoff, cumulative sediment, and sediment/runoff ratio. Significant differences among treatment means were determined by the Tukey-Kramer test $(P<0.05)$.

\section{RESULTS}

\section{Hill Slope Characterization}

The hill slope study site is considered a wooded shrubland (Romme et al. 2009) where Utah juniper has invaded former sagebrush steppe vegetation. Prior to treatment relative tree cover of all perennial plant cover was $62 \%$ (23.1\% tree cover/ $37.4 \%$ total tree, shrub, perennial grass, and perennial forb cover; Table 1). Therefore, the site was in Phase II-III successional condition where trees provide half to more than $2 / 3$ of the relative cover (Miller et al. 2008). Shredding reduced live tree cover to $<1 \%$, which decreased total perennial foliar cover by $20.5 \%$ from $37.4 \%$ to $16.9 \%$. However, shredding decreased total bare ground and rock at the surface by $23.6 \%$ and decreased total non-foliar-covered bare ground and rock by $17 \%$ (Table 1). Shredding tended to reduce shrub cover but increase perennial grass and annual forb cover (Table 1). The shredding vehicle left tire tracks that covered $15 \% \pm 0.02$ SE of the hill slope.

A calcic layer was observed approximately $10 \mathrm{~cm}$ beneath the soil surface and $\mathrm{CaCO}_{3}$ levels varied from $27.1 \%$ to $38.9 \%$ across the site. Volumetric soil water at $10-20-\mathrm{cm}$ depth at the time of shredding at three nearby $(<1.6 \mathrm{~km})$ soil moisture stations as measured by time domain reflectrometry ranged from $20 \%$ to $22 \%$.

\section{Penetration Resistance Across the Hill Slope}

Soil resistance was significantly higher on tracked than untracked interspaces and shrub mounds $(P<0.05)$, and this difference increased with depth of the penetrometer into the soil (Fig. 2). Resistance did not differ $(P \geq 0.05)$ between tracked and untracked points on juniper mounds. Resistance was significantly $(P<0.05)$ higher on untracked juniper than untracked shrub mounds at $7.5 \mathrm{~cm}$ and $10 \mathrm{~cm}$. Soil resistance was not different among other microsites within a tracking treatment.

\section{Runoff Plot Responses}

Microsite Effects. Shrub and grass microsites had greater vegetation cover than juniper mounds, whereas juniper and shrub mounds had greater litter and less rock cover than grass and bare interspaces (Table 2). Surface roughness did not vary significantly $(P \geq 0.05)$ by microsite. There was no measurable runoff for shrub microsites for the dry run. There were few differences in hydrologic responses for different microsites for the dry run, except that untracked juniper mounds had less time to initial and peak runoff than untracked grass or bare interspace microsites (Table 3; Fig. 3). Microsite differences in hydrologic responses were much more pronounced for the wet than the dry run (Table 4; Fig 3). For the wet run, untracked bare interspaces had reduced hydrologic function compared to untracked juniper, shrub, and grass microsites, as indicated by lower final and minimum infiltration rates and greater cumulative runoff, runoff/rain ratio, and cumulative sediment yield. Mean final and minimal infiltration rates on mounds were $0.5-1.5$ times higher than those of bare interspace micosites. Shrub microsites had greater time to initial runoff than the other microsites, while juniper microsites had much less time to peak runoff than the other microsites. 
Table 1. Mean percentage (SE) hill slope vegetation and ground cover before and after shredding Utah juniper trees (Juniperus ostesperma [Torr.] Little) in Utah.

\begin{tabular}{|c|c|c|}
\hline & Before shredding & After shredding \\
\hline \multicolumn{3}{|l|}{ Foliar cover } \\
\hline \multicolumn{3}{|l|}{ Annual grass } \\
\hline Cheatgrass & $<1$ & $<1$ \\
\hline \multicolumn{3}{|l|}{ Annual forbs } \\
\hline Bur buttercup & $1.8(0.4)$ & $2.9(1.3)$ \\
\hline Pale madwort & $<1$ & $<1$ \\
\hline Total & $2.0(0.5)$ & $3.7(1.3)$ \\
\hline Total annual grasses and forbs & $2.0(0.5)$ & $3.7(1.3)$ \\
\hline \multicolumn{3}{|l|}{ Perennial forbs } \\
\hline Ballhead ipomopsis & $<1$ & $<1$ \\
\hline \multicolumn{3}{|l|}{ Perennial grasses } \\
\hline Sandberg bluegrass & $<1$ & $3.2(1.2)$ \\
\hline Bluebunch wheatgrass & $8.6(5.7)$ & $10.6(2.1)$ \\
\hline Total & $9.1(2.1)$ & $13.8(3.3)$ \\
\hline \multicolumn{3}{|l|}{ Shrubs } \\
\hline Black sagebrush & $4.4(1.0)$ & $2.9(0.7)$ \\
\hline Wyoming big sagebrush & $<1$ & $<1$ \\
\hline Total & $5.1(1.2)$ & $3.0(0.6)$ \\
\hline \multicolumn{3}{|l|}{ Trees } \\
\hline Utah juniper & $23.1(2.0)$ & $<1$ \\
\hline Total perennial cover & $37.4(1.4)$ & $16.9(3.7)$ \\
\hline Standing dead & $11.8(1.3)$ & $2.7(0.4)$ \\
\hline \multicolumn{3}{|l|}{ Ground surface } \\
\hline \multicolumn{3}{|l|}{ Ground uncovered } \\
\hline Rocks & $20.2(5.7)$ & $11.1(2.6)$ \\
\hline Bare ground & $38.2(3.3)$ & $23.7(3.8)$ \\
\hline Total & $58.4(3.4)$ & $34.8(2.5)$ \\
\hline \multicolumn{3}{|l|}{ Ground covered } \\
\hline Litter & $37.7(3.3)$ & $23.1(0.9)$ \\
\hline Moss & $3.3(0.3)$ & $1.11(0.1)$ \\
\hline Shredded residue & $\mathrm{N} / \mathrm{A}$ & $40.0(3.4)$ \\
\hline Biologic crust & $<1$ & $0.89(0.7)$ \\
\hline Total & $40.9(3.7)$ & $65.1(2.5)$ \\
\hline \multicolumn{3}{|c|}{ Uncovered ground with no foliar cover } \\
\hline Rocks & $15.4(2.0)$ & $11.9(4.1)$ \\
\hline Bare ground & $32.2(2.5)$ & $18.8(2.7)$ \\
\hline Total & $47.7(1.2)$ & $30.7(2.3)$ \\
\hline
\end{tabular}

Tracking Effects. Across all microsites, untracked runoff plots had greater rock cover $(P<0.05)$ than tracked plots $(21.6 \% \pm 1.9$ vs. $13.5 \% \pm 1.9)$. Rock cover was especially greater on tracked than untracked bare interspace microsites (Table 2). Tracking did not significantly affect $(P \geq 0.05)$ surface roughness and had little effect on grass or forb cover (Table 2). Tracking did reduce shrub cover $(P>0.05)$ from $51 \%$ to $18 \%$ and significantly reduced $(P>0.05)$ total foliar cover on shrub microsites.

There were no significant differences in measured hydrologic responses between untracked and tracked microsites for the dry run, although there was a trend toward lower infiltration and higher runoff and sediment produced on the tracked plots
(Table 3; Fig. 3A). For the wet run, tracked shrub microsites had much less time to initial runoff than untracked microsites, and tracked grass interspace microsites had lower final and minimum infiltration rates than untracked microsites (Table 4; Fig. 3B). The greatest effect from tracking was the $40 \%$ reduction in final infiltration rate and $42 \%$ reduction in minimal infiltration rate on grass interspace plots (Table 3; Fig. 3B). Although tracking produced no other statistically significant effects $(P \geq 0.05)$, tracked plots had a trend toward reduced hydrologic function for most microsites.

Residue Effects. On residue-covered plots, grass microsite plots had much higher non-residue-litter cover than did bare (vegetation-free) interspace plots (Table 2). Residue also covered rocks and therefore reduced rock cover on these plots. Mulch residue did not significantly affect $(P \geq 0.05)$ runoff plot vegetation cover.

The dry run did not have any measurable runoff on most mulch-residue-covered plots and therefore was not analyzed. For the wet run, residue-covered plots had higher final and minimum infiltration rates and lower cumulative runoff, runoff/rain ratio, and cumulative sediment produced on bare interspace microsites than nonresidue plots. Residue had little effect on grass interspace microsites once runoff began (Table 4; Fig. 3C). Residue-covered bare interspace microsites had $67 \%$ higher final infiltration rates and $69 \%$ higher minimal infiltration rates than nonresidue plots. For these plots, a minimum residue cover for three plots of $2.2 \% \pm 0.84$ SE was associated with a maximum cumulative sediment production of $333 \mathrm{~g} \cdot \mathrm{m}^{-2} \pm 79.0 \mathrm{SE}$, while a maximum residue cover of $61.0 \%( \pm 6.34)$ was associated with a minimal cumulative sediment production of $33.5 \mathrm{~g} \cdot \mathrm{m}^{-2} \pm 6.75 \mathrm{SE}$.

\section{DISCUSSION}

\section{Compaction and Infiltration Responses to Tire Tracks}

Does tire tracking from a heavy shredding vehicle increase soil compaction? Hatchett et al. (2006) measured soil resistance as an index of compaction in shredded Pinus spp. and Calocedrus spp. forests and found little effect from the shredding vehicle. In our study, it appears that juniper litter and duff layers acted similarly as the tree litter in their study to cushion and absorb the compression of the weight of the vehicle. Compaction from agricultural vehicles has been well documented (Hamlett et al. 1990; Raper 2005). In our study, tracking significantly increased soil resistance one- to threefold for bare interspace, grass interspace, and shrub mound microsites. Litter fall in these microsites offers little protection from vehicle compaction. Although increased compaction from vehicular tracking is consistent with agricultural studies, shredding to control juniper trees does not involve repeated passes over the same soil year after year. Rather, shredding of juniper woodland may not have to be repeated for several decades. Rangeland soils are highly variable temporally in antecedent soil water content and highly variable spatially in texture, percentage of coarse fragments, and organic matter composition (Coronato and Bertiller 1995; Reeder 2002). Increased compaction, reduced infiltration, and increased sediment movement from tracking is expected to be most pronounced on soils that are wet during 


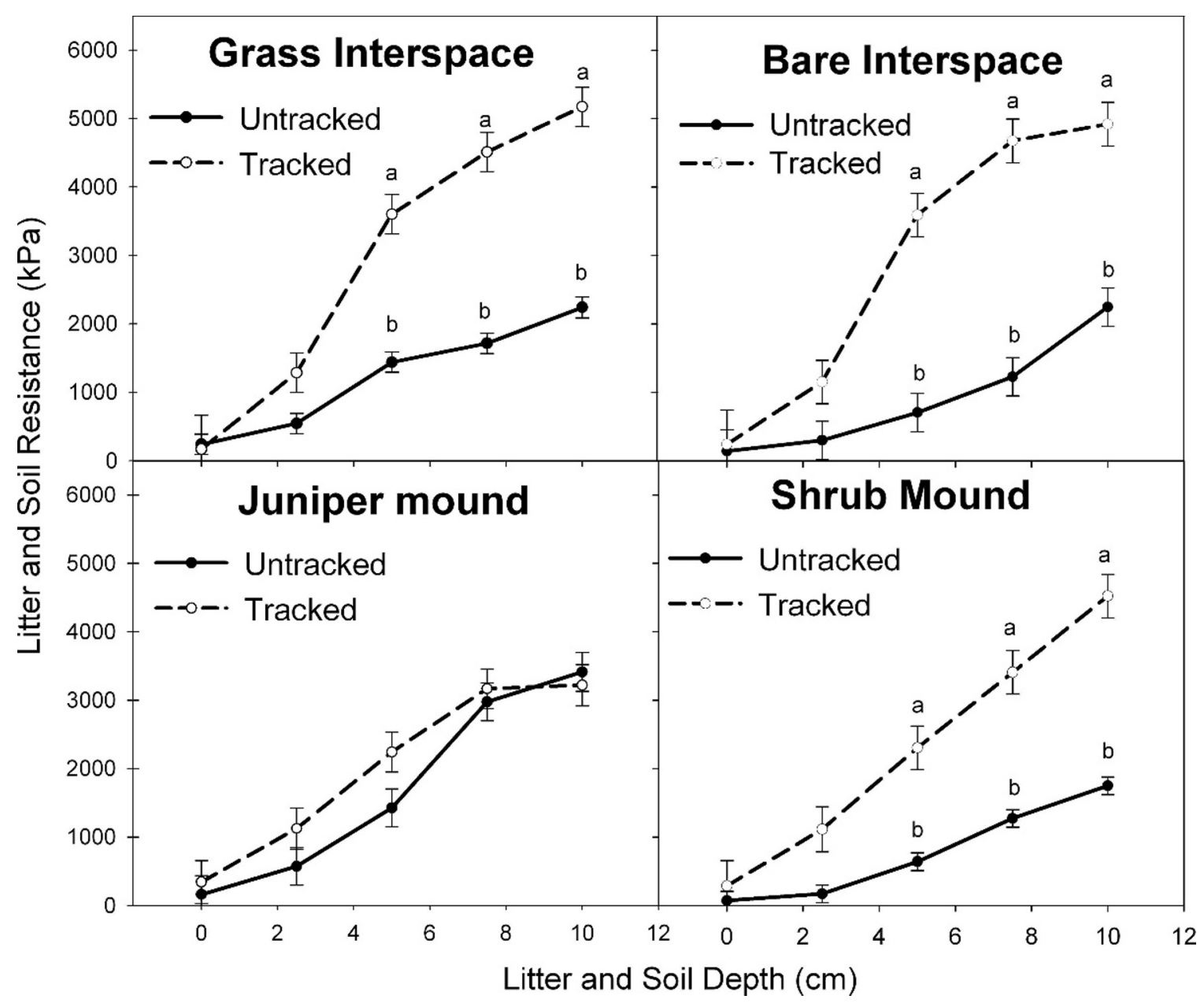

Figure 2. Soil resistance by microsite with and without tracking from a rubber-tired tree shredder. Graphs indicate soil resistance from cone penetrometer as depth increases. Letters "a" and "b" above standard error bars indicate significant differences between untracked and tracked soils at that depth as determined by the Tukey-Kramer test $(P<0.05)$.

treatment, and on fine-textured soils, with low organic matter and low aggregate stability.

Does compaction decrease infiltration? Hydrologic responses from tracking varied with microsite type; tracking significantly decreased final and minimal infiltration rates only on grass interspaces. Decreased soil porosity is presumably responsible for this response as has been found from compaction by agricultural vehicles on agricultural soils (Berli et al. 2004). As tires roll over grass microsites the pressure and weight of the shredding vehicle probably reduce the porosity created by the grass fibrous root system, leaving the soil with fewer and more restricted infiltration pathways. Bare interspaces lack the porosity of grass interspaces, tree mounds, and shrub mounds and typically have lower infiltration rates than vegetated mounds and microsites (Blackburn 1975; Roundy et al. 1978; Reid et al. 1999). Wilcox et al. (2003) suggested that macropores under some juniper trees may provide for higher infiltration rates on mounds than bare interspaces. In our study, mounds had up to $300 \%$ higher infiltration rates than bare interspaces, suggesting the presence of macropores. The difference between mounds and interspaces is consistent with previous research (Rau et al. 2005; Pierson et al. 2007a). Juniper microsites had the least time to initial and peak runoff, suggesting the presence of a water-repellent layer (Roundy et al. 1978; Leighton-Boyce et al. 2007; Madsen et al. 2008). The high infiltration rate of juniper microsites in our study suggests that water found open macro- or micropores to infiltrate the soil after some initial runoff from these layers.

Eldridge and Rosentreter (2004) attributed the higher infiltration rates of shrub mounds than interspaces to the presence of soil macropores. In our study, shrub mounds also had significantly higher final and minimal infiltration rates than interspaces. Tracking significantly decreased the time to initial runoff on shrub mounds. Tracking flattened shrub canopies and probably reduced rainfall interception. Evidence of this is the decreased time-to-runoff on tracked shrub plots (Table 3). The lack of significance of these trends suggests that the macropores on shrub mound plots were, to some degree, still intact and permitting high infiltration rates.

In our study, surface roughness was not significantly changed by tracking. This was an unexpected result. Large tire tracks observed across the site were thought to increase surface roughness and thereby provide either catchment run-in areas for tracks perpendicular to the slope or avenues for rills for tracks parallel to the slope. Untracked microsites had a significantly higher percentage of rock cover than tracked microsites. It is likely that rocks were pushed into the soil and 
Table 2. Mean ( \pm SE) ground and vegetation cover (\%) on runoff plots in shredded Utah juniper woodland by microsite.

\begin{tabular}{|c|c|c|c|c|c|c|c|c|c|c|}
\hline & \multicolumn{4}{|c|}{ Untracked } & \multicolumn{4}{|c|}{ Tracked } & \multicolumn{2}{|c|}{ Mulch residue } \\
\hline & Juniper & Shrub & Grass & Bare & Juniper & Shrub & Grass & Bare & Grass & Bare \\
\hline Perennial grass & $14.1 \pm 4.63$ & $25.7 \pm 4.63$ & $34.3 \pm 4.63$ & $0.76 \pm 4.63$ & $8.57 \pm 5.17$ & $16.2 \pm 4.63$ & $18.4 \pm 4.22$ & $0.76 \pm 4.62$ & $19.8 \pm 5.17$ & $1.67 \pm 5.17$ \\
\hline Perennial forb & $3.24 \pm 2.36$ & $7.81 \pm 2.36$ & $6.86 \pm 2.36$ & $0.38 \pm 2.36$ & $3.46 \pm 2.62$ & $2.29 \pm 2.36$ & $2.14 \pm 2.19$ & $0.57 \pm 2.36$ & $2.50 \pm 2.62$ & $0.21 \pm 2.62$ \\
\hline Shrub & $0.19 \pm 2.62$ & $50.7 \pm 2.62$ & $0.19 \pm 2.62$ & $0.00 \pm 2.62$ & $0.00 \pm 2.93$ & $17.9 \pm 2.62$ & $1.11 \pm 2.39$ & $0.00 \pm 2.62$ & $0.00 \pm 2.93$ & $0.00 \pm 2.93$ \\
\hline Standing dead & $0.00 \pm 0.54$ & $1.52 \pm 0.54$ & $0.00 \pm 0.54$ & $0.19 \pm 0.54$ & $0.24 \pm 0.60$ & $0.00 \pm 0.54$ & $0.00 \pm 0.49$ & $0.38 \pm 0.54$ & $0.71 \pm 0.60$ & $0.00 \pm 0.60$ \\
\hline Annual forb & $2.10 \pm 1.11$ & $0.00 \pm 1.11$ & $0.38 \pm 1.11$ & $0.57 \pm 1.11$ & $2.10 \pm 1.11$ & $0.76 \pm 1.11$ & $0.79 \pm 1.01$ & $0.19 \pm 1.11$ & $0.00 \pm 1.24$ & $3.57 \pm 1.24$ \\
\hline Total foliar cover & $24.8 \pm 5.50$ & $94.3 \pm 5.50$ & $47.8 \pm 5.50$ & $3.43 \pm 5.50$ & $12.5 \pm 6.15$ & $59.6 \pm 5.50$ & $31.6 \pm 5.03$ & $3.24 \pm 5.50$ & $23.0 \pm 6.15$ & $5.15 \pm 6.15$ \\
\hline Litter & $58.7 \pm 8.22$ & $48.8 \pm 8.22$ & $19.6 \pm 8.22$ & $1.90 \pm 8.22$ & $56.5 \pm 9.13$ & $46.7 \pm 8.22$ & $17.9 \pm 7.53$ & $3.62 \pm 8.22$ & $17.9 \pm 9.13$ & $2.70 \pm 9.13$ \\
\hline Rock & $0.95 \pm 3.79$ & $10.9 \pm 3.79$ & $31.4 \pm 3.79$ & $46.7 \pm 3.79$ & $1.67 \pm 4.24$ & $12.4 \pm 3.79$ & $15.1 \pm 3.46$ & $24.8 \pm 3.79$ & $6.42 \pm 4.24$ & $7.38 \pm 4.24$ \\
\hline Bare & $2.37 \pm 6.20$ & $30.7 \pm 6.20$ & $37.7 \pm 6.20$ & $46.7 \pm 6.14$ & $7.86 \pm 6.93$ & $25.5 \pm 6.20$ & $47.0 \pm 5.66$ & $67.4 \pm 6.20$ & $20.5 \pm 6.93$ & $13.6 \pm 6.93$ \\
\hline
\end{tabular}

possibly covered, resulting in a smoother track and the lack of difference in surface roughness.

Track orientation was not studied, however, on tracks both parallel and perpendicular to the slope, and depressions were observed to result in ponding on some plots. Some rilling was observed in tracks parallel to the slope. Significance of rilling associated with tracks deserves further study at the hill slope scale.

\section{Mulch Residue}

Does a mulch residue reduce sediment yields and increase infiltration rates? Because our method calculated infiltration as the difference between water applied and runoff, it did not take into account interception storage associated with mulch residues. Therefore the residue may have been more effective in reducing runoff than strictly increasing infiltration in our study. Nevertheless, shredded tree residues were definitely beneficial in reducing runoff and sediment from bare interspaces. Bare interspaces have been found to have higher sediment yields than tree interspaces with understory vegetation and tree canopies at a patch scale $\left(1 \mathrm{~m}^{2}\right.$; Reid et al. 1999). Hastings et al. (2003) found that leaving juniper slash on New Mexico watersheds can reduce sediment loads by one- to threefold. Pine-needle mulch cover (various species) has been found to reduce sediment yields by half, an effect similar to that of vegetation restoration treatments (Grismer and Hogan 2005). Radcliffe et al. (1988) have suggested that in agricultural practices, the hydrologic benefits of the "no till" method are largely attributed to accumulation of ground debris disrupting rain drop impact, which increased infiltration rates. They further indicated that the soil covering may have a repairing effect on compacted soils over time. This repair could occur by organic matter additions, which increase soil aggregate stability and porosity over time.

The results of our study are consistent with those of previous work. Mulch residue decreased sediment yield on bare interspace plots by approximately $87 \%$, while increasing infiltration rates by approximately $67 \%$ (Table 3 ). The reductions in sediment yields may be a result of increased interception storage associated with the residue, reduced raindrop impact as reported in laboratory experiments by Geddes and Dunkerley (1999) and Kramer and Meyer (1969), or both effects. High infiltration rates are associated with lower sediment yields (Walker et al. 2007). The significant drop in sediment produced with an increase in residue cover is strong evidence that residue intercepts raindrops, reduces runoff, and greatly reduces sediment (Table 4). It is also possible that mulch residue provides resistance to interrill flow similar to resistance provided by vegetation. Gutierrez and Hernandez (1996) show that grass cover is negatively correlated with sediment production and that grass may also resist interrill flow. Vegetation and residue resistance to interrill flow would allow sediment to settle out of runoff water and permit more time for infiltration to occur. Reid et al. (1999) suggest that intercanopy vegetation may function as a sink for runoff, and Ernest et al. (1993) suggest that slash material acts as an obstacle to prevent sheet erosion. We surmise that both raindrop interception and interrill obstruction play a role in the reduction of runoff and sediment yields.

Although compaction decreased infiltration rates on grass interspaces, mulch residue evidently increased interception storage while decreasing runoff and sediment yield on bare

Table 3. Dry run (soil initially dry) infiltration, runoff, and sediment rates on a shredded Utah juniper woodland in Utah. Different letters within a row indicate significantly different means by the Tukey-Kramer test $(P<0.05)$.

\begin{tabular}{|c|c|c|c|c|c|c|}
\hline & \multicolumn{2}{|c|}{ Juniper mound } & \multicolumn{2}{|c|}{ Grass interspace } & \multicolumn{2}{|c|}{ Bare interspace } \\
\hline & Untracked & Tracked & Untracked & Tracked & Untracked & Tracked \\
\hline Number of plots out of five with runoff & 3 & 3 & 3 & 3 & 5 & 5 \\
\hline Time to runoff (min) & $6.00 \mathrm{~b}$ & $4.10 \mathrm{~b}$ & $24.80 \mathrm{a}$ & $16.20 \mathrm{a}$ & $13.80 a b$ & $18.80 \mathrm{a}$ \\
\hline Time-to-peak runoff (min) & $17.60 \mathrm{~b}$ & $25.60 \mathrm{ab}$ & $41.30 \mathrm{a}$ & $39.80 \mathrm{a}$ & $42.60 \mathrm{a}$ & $39.00 \mathrm{a}$ \\
\hline Cumulative runoff (mm) & $6.98 \mathrm{a}$ & $9.61 \mathrm{a}$ & $2.98 \mathrm{a}$ & $10.60 \mathrm{a}$ & $13.30 \mathrm{a}$ & $12.80 \mathrm{a}$ \\
\hline Runoff/rain ratio $\left(\mathrm{mm} \cdot \mathrm{mm}^{-1}\right)$ & $0.15 a$ & $0.21 \mathrm{a}$ & $0.06 \mathrm{a}$ & $0.23 \mathrm{a}$ & $0.28 \mathrm{a}$ & $0.27 \mathrm{a}$ \\
\hline Cumulative sediment $\left(\mathrm{g} \cdot \mathrm{m}^{-2}\right)$ & $29.20 \mathrm{a}$ & $37.60 \mathrm{a}$ & $16.10 \mathrm{a}$ & $77.70 \mathrm{a}$ & $62.00 \mathrm{a}$ & $83.50 \mathrm{a}$ \\
\hline Sediment/runoff ratio $\left(\mathrm{g} \cdot \mathrm{m}^{-2} \cdot \mathrm{mm}^{-1}\right)$ & $3.77 \mathrm{~b}$ & $3.81 \mathrm{~b}$ & $4.38 \mathrm{ab}$ & $7.07 \mathrm{ab}$ & $4.88 \mathrm{ab}$ & $7.66 \mathrm{a}$ \\
\hline
\end{tabular}




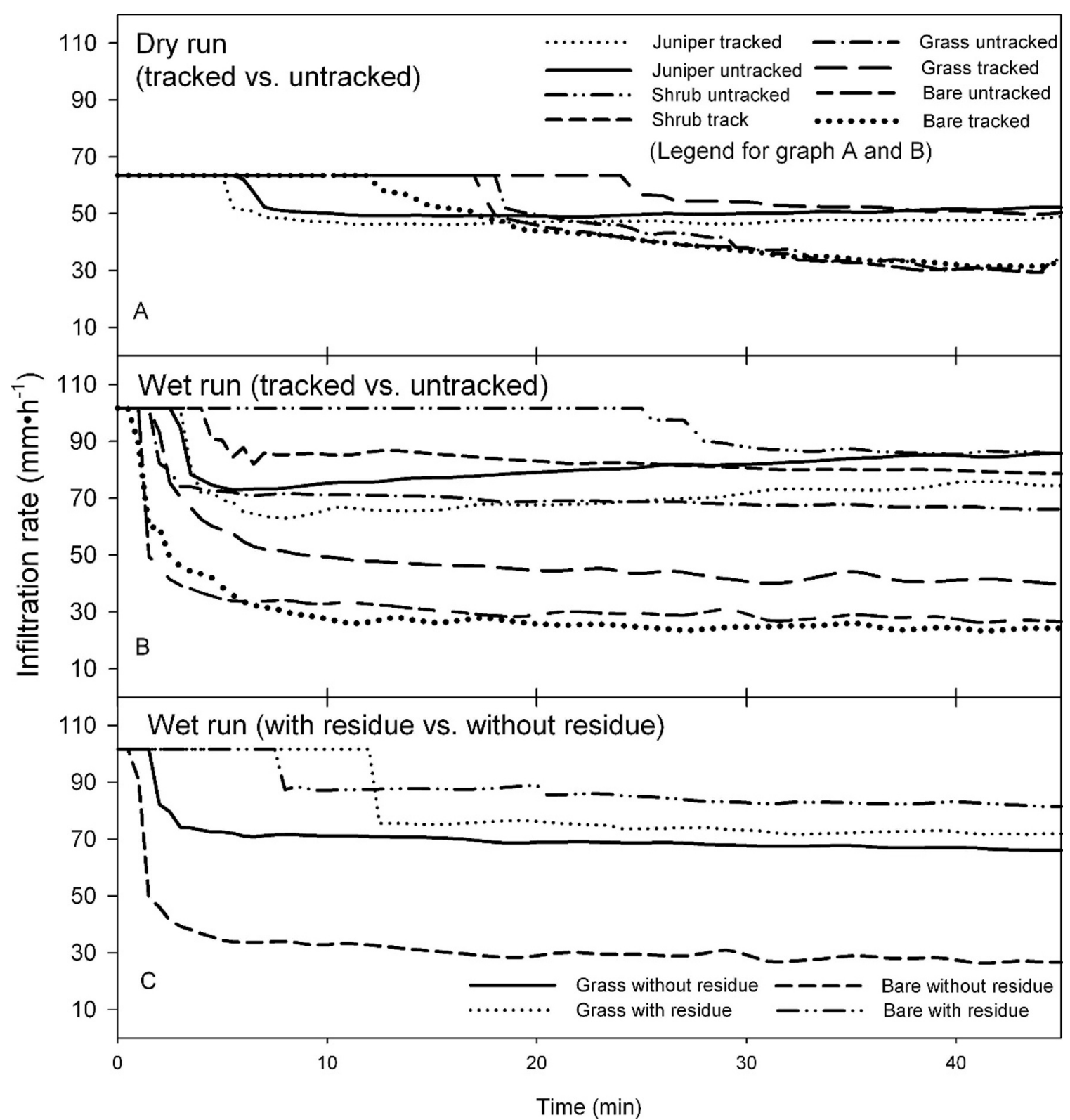

Figure 3. Infiltration rates for tracked and untracked microsites for A, initially dry (dry run), and B, initially wet (wet run) soils and C, bare and residue-covered interspaces in a Utah juniper woodland after tree shredding.

Table 4. Wet run (soil initially wet) infiltration, runoff, and sediment rates on a shredded Utah juniper woodland in Utah. Different letters within a row and tracked or residue treatment indicate significantly different means by the Tukey-Kramer test $(P<0.05)$.

\begin{tabular}{|c|c|c|c|c|c|c|c|c|c|c|c|c|}
\hline & \multicolumn{8}{|c|}{ Tire tracks } & \multicolumn{4}{|c|}{ Juniper residue } \\
\hline & \multicolumn{2}{|c|}{ Juniper mound } & \multicolumn{2}{|c|}{ Shrub mound } & \multicolumn{2}{|c|}{ Grass interspace } & \multicolumn{2}{|c|}{ Bare interspace } & \multicolumn{2}{|c|}{ Grass interspace } & \multicolumn{2}{|c|}{ Bare interspace } \\
\hline & Untracked & Tracked & Untracked & Tracked & Untracked & Tracked & Untracked & Tracked & No residue & Residue & No residue & Residue \\
\hline Number of plots out of five with runoff & 5 & 5 & 3 & 4 & 5 & 5 & 5 & 5 & 5 & 3 & 5 & 4 \\
\hline Final infiltration $\left(\mathrm{mm} \cdot \mathrm{h}^{-1}\right)$ & $85.70 \mathrm{a}$ & $74.20 \mathrm{a}$ & $85.00 \mathrm{a}$ & $79.30 \mathrm{a}$ & $66.10 \mathrm{a}$ & $39.80 \mathrm{~b}$ & $26.70 \mathrm{~b}$ & $24.20 \mathrm{~b}$ & $66.10 \mathrm{a}$ & $67.30 \mathrm{a}$ & $26.70 \mathrm{~b}$ & $81.90 \mathrm{a}$ \\
\hline Minimum infiltration $\left(\mathrm{mm} \cdot \mathrm{h}^{-1}\right)$ & $71.70 \mathrm{a}$ & $62.60 a b$ & $83.00 \mathrm{a}$ & $77.00 \mathrm{a}$ & $65.40 \mathrm{a}$ & $37.70 \mathrm{bc}$ & $24.00 \mathrm{c}$ & $20.10 \mathrm{c}$ & $65.40 \mathrm{a}$ & $62.70 a b$ & $24.00 \mathrm{~b}$ & $78.10 \mathrm{a}$ \\
\hline Time to runoff (min) & $3.55 \mathrm{bc}$ & $3.64 \mathrm{bc}$ & $25.50 \mathrm{a}$ & $4.50 \mathrm{~b}$ & 1.86 cde & $2.91 \mathrm{bcd}$ & d $1.02 \mathrm{e}$ & $1.22 \mathrm{de}$ & $1.86 \mathrm{a}$ & $12.50 \mathrm{a}$ & $1.02 \mathrm{a}$ & $7.66 \mathrm{a}$ \\
\hline Time-to-peak runoff (min) & $8.30 \mathrm{~b}$ & $8.24 \mathrm{~b}$ & $40.30 \mathrm{a}$ & $31.90 \mathrm{a}$ & $36.60 \mathrm{a}$ & $40.40 \mathrm{a}$ & $43.30 \mathrm{a}$ & $31.90 \mathrm{a}$ & $36.60 \mathrm{a}$ & $23.30 \mathrm{a}$ & $43.30 \mathrm{a}$ & $29.50 \mathrm{a}$ \\
\hline Cumulative runoff (mm) & $14.30 \mathrm{c}$ & $20.20 \mathrm{bc}$ & $4.66 \mathrm{c}$ & $12.20 \mathrm{c}$ & $22.50 \mathrm{bc}$ & $38.30 \mathrm{ab}$ & $52.10 \mathrm{a}$ & $52.70 \mathrm{a}$ & $22.50 \mathrm{~b}$ & $24.10 a b$ & $52.10 \mathrm{a}$ & $11.10 \mathrm{~b}$ \\
\hline Runoff/rain ratio $\left(\mathrm{mm} \cdot \mathrm{mm}^{-1}\right)$ & $0.19 \mathrm{c}$ & $0.27 \mathrm{bc}$ & $0.06 \mathrm{c}$ & $0.16 \mathrm{c}$ & $0.30 \mathrm{bc}$ & $0.51 \mathrm{ab}$ & $0.68 \mathrm{a}$ & $0.69 \mathrm{a}$ & $0.30 \mathrm{~b}$ & $0.32 \mathrm{ab}$ & $0.68 \mathrm{a}$ & $0.15 \mathrm{~b}$ \\
\hline Cumulative sediment $\left(\mathrm{g} \cdot \mathrm{m}^{-2}\right)$ & $48.80 \mathrm{c}$ & $75.00 \mathrm{bc}$ & $20.90 \mathrm{c}$ & $70.50 \mathrm{bc}$ & 133.00 bc 2 & $211.00 \mathrm{ab}$ & $313.00 \mathrm{a}$ & $403.00 \mathrm{a}$ & $133.00 \mathrm{~b}$ & $83.80 \mathrm{~b}$ & $313.00 \mathrm{a}$ & $38.60 \mathrm{~b}$ \\
\hline Sediment/runoff ratio $\left(\mathrm{g} \cdot \mathrm{m}^{-2} \cdot \mathrm{mm}^{-1}\right)$ & $3.40 \mathrm{~b}$ & $3.69 \mathrm{~b}$ & $4.96 \mathrm{ab}$ & $5.77 \mathrm{ab}$ & $5.46 \mathrm{ab}$ & $5.51 \mathrm{ab}$ & $6.08 \mathrm{ab}$ & $7.68 \mathrm{a}$ & $5.46 \mathrm{a}$ & $3.57 \mathrm{a}$ & $6.07 \mathrm{a}$ & $3.49 a$ \\
\hline
\end{tabular}


interspaces. The Onaqui study site was estimated to have tire tracks that covered $15 \%$ of the study site, while mulch residue was estimated to cover $40 \%$ (Table 1). Although tree shredding reduced perennial foliar cover by $20.5 \%$, shredding reduced non-foliar-covered bare ground and rock by $17 \%$ (Table 1 ). Bare ground coverage by shredding will vary depending on tree density and operational procedures.

Mulch residue generated from mechanical shredding increased infiltration rates and decreased sediment yields for bare interspaces. Surface cover from litter or residue was associated with increased infiltration in this study even though penetration resistance measurements indicated that soils were physically compacted from vehicle pressure during tree shredding. Increased infiltration and decreased erosion are considered positive hydrologic effects for semiarid soils because they maintain functional water and nutrient cycles. Increased microsite infiltration should be expected to reduce runoff and sediment loss at hill slope and watershed scales. Tree control treatments such as burning, cabling, and chaining have been shown to have highly variable hydrologic responses in simulated-rainfall, microsite, and intercanopy-scale studies (Roundy and Vernon 1999). Soil cover and texture and other site variables have generally been shown to have a greater effect on hydrologic responses than treatments in these studies. Because compaction from shredding had limited effects on infiltration rates, while shredded residue increased interspace infiltration, we suggest that shredding compares favorably with the hydrologic responses from these other treatments and should generally have a beneficial effect on site hydrologic function.

\section{Relevance of Results to Other Sites}

Juniper reduction treatments are recommended on Phase I and II woodlands to prevent additional understory loss and associated potential erosion or catastrophic fire and weed invasion as woodlands progress to Phase III (Miller et al. 2008; Tausch et al. 2009). Our site is typical of those recommended for tree reduction to address these concerns. The site supported 453 trees $\cdot \mathrm{ha}^{-1}$ prior to treatment and represented Phase II to III woodland. Erosion on juniper woodlands that lose their understory is highly dependent on soil erosion potential of the site (Roundy and Vernon 1999). Sites with steep slopes, fine soil textures, and high incidence of summer thundershowers have the highest soil erosion potential. Understory vegetation patches may interrupt rills that otherwise could coalesce and concentrate runoff, thereby substantially increasing erosion (Davenport et al. 1998; Reid et al. 1999; Wilcox et al. 2003). Such a result can be considered the passing of an abiotic threshold (Davenport et al. 1998; Whisenant 1999; Wilcox et al. 2003). The effects of understory loss and the potential for this scenario on specific juniper sites is not well known but is considered less likely on sites with less soil erosion potential. The loamy soil texture of our site and its native high infiltration rate indicate that it should not be considered to have high soil erosion potential. Runoff from juniper woodlands in the northwestern United States is considered to be limited because low-intensity winter rainstorms are the dominant precipitation (Wilcox et al. 2003). However, the $15 \%$ slope, shallow soil, and potential for infrequent, but eventual high-intensity thundershowers of the Onaqui site suggests that major erosion could occur without treatments to reduce trees and allow the understory vegetation to recover. The typical soil texture and slope of the Onaqui site make it fairly representative of numerous other alluvial slopes on the fault-block mountains of the Great Basin. Although hydrologic responses to treatments of juniper woodlands can be highly site specific, our results should be considered representative of similar sites and soils.

\section{IMPLICATIONS}

Tracking from mechanical shredding (or Bull Hog) resulted in some adverse hydrologic effects on grass interspaces under conditions of initially wet soils and a high simulated rainfall. However, juniper woodlands are typically shredded where tree densities are high and have reduced understory grasses. Residues from shredding decreased bare ground and were associated with increased infiltration rates and decreased sediment yields on bare interspaces. We conclude that juniper shredding had an overall beneficial effect on infiltration and reduction of sediment at the microsite scale on the studied hill slope. Site and temporal characteristics should always be considered when applying mechanical treatments because specific soil conditions may be associated with low infiltration. Land managers should be aware of factors that promote soil compaction such as high soil water content, heavy loads, repeated passes, soil disturbance, and the generation of fine sediments (Raper 2005). Sites with coarser-textured soils and higher infiltration rates or finer-textured soils with lower infiltration rates may respond differently to tracking and shredded residue than soils at the Onaqui site. Managers should watch for evidence of rills and coalescing of rills before and after treatments to best evaluate hydrologic responses at the hill slope and larger scales. Where possible, vehicle drivers should shred trees to spread the mulch residue as much as possible to increase the functional hydrology of interspaces.

\section{ACKNOWLEDGMENTS}

We thank Brad Jessop, Matthew Madsen, Richard E. Terry, and Steven L. Petersen for their review and advice. We thank the Northwest Watershed Research Center field crew for help in making measurements. We also thank Hyla Cline for help in collecting data.

\section{LITERATURE CITED}

Baker, W. L., and D. J. Shinneman. 2004. Fire and restoration on piñon-juniper woodlands in the western United States: a review. Forest Ecology and Management 189:1-21.

Bates, J. D., R. F. Mlller, and T. J. Svejcar. 2000. Understory dynamics in cut and uncut western juniper woodlands. Journal of Range Management 53:119-126.

Benson, T. L. 2006. Understory vegetation responses to pinyon-juniper tree removal, seeding, and chip application, Lincoln County, Nevada [thesis]. Ann Arbor, MI, USA: University of Nevada. 114 p.

Berli, M., B. Kulli, W. Attinger, M. Keller, J. Leuenberger, H. Flühler, S. M. Springman, and R. Schulin. 2004. Compaction of agricultural and forest subsoils by tracked heavy construction machinery. Soil and Tillage Research 75:37-52. 
BlackBURN, W. H. 1975. Factors influencing infiltration and sediment production of semiarid rangelands in Nevada. Water Resources Research 11:929937.

Blanco-Canqui, H., and R. Lal. 2007. Impacts of long-term wheat straw management on soil hydraulic properties under no-tillage. Soil Science Society of America Journal 71:1166-1173.

Bruand, A., AND I. Cousin. 1995. Variation of textural porosity of a clay-loam soil during compaction. European Journal of Soil Science 46:377-385.

Busby, F. E., AND G. F. GIFFord. 1981. Effects of livestock grazing on infiltration and erosion rates measured on chained and unchained pinyon-juniper woodlands. Journal of Range Management 53:119-126.

Chambers, J. C., S. B. Vander Wall, and E. W. Schupp. 1999. Seed and seedling ecology of piñon and juniper species in the pygmy woodlands of western North America. Botanical Review 65:1-38.

Coronato, F. R., and M. B. Bertiller. 1995. Precipitation and landscape related effects on soil moisture in semi-arid rangelands of Patagonia. Journal of Arid Environments 34:1-9.

D’Antonio, C. M., and P. M. Vitousek. 1992. Biological invasions by exotic grasses, the grass/fire cycle, and global change. Annual Review Ecology and Systematics 23:63-87.

Davenport, D. W., D. D. Breshears, B. P. Wilcox, and C. D. Allen. 1998. Viewpoint Sustainability of piñyon-juniper ecosystems: a unifying perspective of soil erosion thresholds. Journal Range Management 51:231-240.

Eldridge, D. J., And R. Rosentreter. 2004. Shrub mounds enhance water flow in a shrub-steppe community in southwestern Idaho, U.S.A. In: A. L. Hild, N. L. Shaw, S. E. Meyer, T. D. Booth, and D. E. McArthur [eDs.]. Seed and soil dynamics in shrubland ecosystems. Ogden, UT, USA: US Department of Agriculture, Forest Service. p. 77-83.

Ennest, K. A., E. F. Aldon, and E. Muldavin. 1993. Woody debris in undisturbed piñon-juniper woodlands of New Mexico. In: E. F. Aldon and D. W. Shaw [EDS.]. Managing pinyon-juniper ecosystems for sustainability and social needs. Fort Collins, CO, USA: US Department of Agriculture, Forest Service. p. $117-123$.

Geddes, N., And D. Dunkerley. 1999. The influence of organic litter on the erosive effects of raindrop and of gravity drops released from desert shrubs. Catena 36:303-313

Grismer, M. E., AND M. P. Hogan. 2005. Simulated rainfall evaluation of revegetation/mulch erosion control in the Lake Tahoe Basin. 1. Method assessment. Land Degradation \& Development 15:573-588.

Gutierrez, J., and I. I. Hernandez. 1996. Runoff and interrill erosion as affected by grass cover in a semi-arid rangeland of northern Mexico. Journal of Arid Environments 34:287-295.

Haan, M. M., J. L. Kovar, J. L. Benning, J. R. Russell, and W. J. Powers. 2006. Grazing management effects on sediment and phosphorus in surface runoff. Rangeland Ecology \& Management 59:607-615.

Hamlett, J. M., S. W. Melvin, and R. HoRton. 1990. Traffic and soil amendment effect on infiltration and compaction. Transactions of the ASAE 33: 821-826.

Hastings, B. K., F. M. Smith, AND B. F. JacoBs. 2003. Rapidly eroding pinon-juniper woodlands in New Mexico: response to slash treatment. Journal of Environmental Quality 32:1290-1298.

Hatchett, B., M. P. Hogan, and M. E. Grismer. 2006. Mechanical mastication thins Lake Tahoe forest with few adverse impacts. California Agriculture AprilJune:77-82.

Kramer, L. A., and L. D. Meyer. 1969. Small amounts of surface mulch reduce soil erosion and runoff velocity. Transactions of the ASAE 12:638-641, 645

Leighton-Boyce, G., S. H. Doerr, R. A. Shakesby, and R. P. D. Walsh. 2007. Quantifying the impact of soil water repellency on overland flow generation and erosion: a new approach using rainfall simulation and wetting agent on in situ soil. Hydrological Processes 21:2337-2345.

Linse, S. J., D. E. Mergen, J. L. Smith, and M. J. Trlica. 2001. Upland erosion under a simulated most damaging storm. Journal of Range Management 54:356-361

LitTell, R. C., G. A. Milliken, W. W. Stroup, and R. D. Wolfinger. 1996. SAS system for mixed models. Cary, NC, USA: SAS Institute Inc. 633 p.
Madsen, M. D., D. G. Chandler, and J. Belnap. 2008. Spatial gradients in ecohydrologic properties with a pinyon-juniper ecosystem. Ecohydrology 1:349-360.

Meyer, L. D., and W. C. Harmon. 1979. Multiple-intensity rainfall simulator for erosion research on row sideslopes. Transactions of the ASAE 22:100-103.

MIllek, R., AND R. TAUSCH. 2002. The role of fire in juniper and pinyon woodlands: a descriptive analysis. In: K. E. M. Galley and T. P. Wilson [EDs.]. Invasive species workshop: the role of fire in the control and spread of invasive species. Tallahassee, FL, USA: Tall Timbers Research Station. p. 15-30.

Miller, R. F., R. J. Tausch, E. D. McArthur, D. D. Johnson, and S. C. Sanderson. 2008. Age structure and expansion of piñon-juniper woodlands: a regional perspective in the Intermountain West. Research Paper RMRS-RP-69. Fort Collins, CO, USA: US Department of Agriculture, Forest Service, Rocky Mountain Station. 15 p.

MilleR, R. F., and P. E. Wigand. 1994. Holocene changes in semiarid pinyon-juniper woodlands. BioScience 44:465-474

Mueller-Dombois, D., and H. Ellenberg. 1974. Aims and methods of vegetation ecology. New York, NY, USA: John Wiley and Sons. p. 81-92.

National Oceanic and Atmospheric Administration. 2009. National Oceanic and Atmospheric Administration. Available at: http://hdsc.nws.noaa.gov. Accessed 15 October 2009.

NeaL, S. M. 2007. Tree thinning treatments alter soil properties, arbuscular mycorrhizal fungi and understory plant communities [thesis]. Flagstaff, AZ, USA: Northern Arizona University. $73 p$.

Noss, R. F., E. T. Laroe III, and J. M. Scott. 1995. Endangered ecosystems of the United States: a preliminary assessment of loss and degradation. Washington, DC, USA: US Department of the Interior, National Biological Service, Biological Report 28. 58 p.

Petersen, S. L., and T. K. Stringham. 2008. Infiltration, runoff, and sediment yield in response to western juniper encroachment in southeast Oregon. Rangeland Ecology \& Management 61:74-81.

Pierson, F. B., J. D. Bates, T. J. Svejcar, and S. P. Hardegree. 2007a. Runoff and erosion after cutting western juniper. Rangeland Ecology \& Management 60:285-292.

Pierson, F. B., W. H. Blackburn, and S. S. Van Vactor. 2007b. Hydrologic impacts of mechanical seeding treatments on sagebrush rangelands. Rangeland Ecology \& Management 60:666-674.

Pierson, F. B., C. A. Moffet, C. J. Williams, S. P. Hardegree, and P. E. Clark. 2009. Prescribed-fire effects on rill and interrill runoff and erosion in a mountainous sagebrush landscape. Earth Surface Processes and Landforms 34: 193-203.

Pierson, F. B., P. R. Robichaud, C. A. Moffet, K. E. Spaeth, S. P. Hardegree, P. E. Clark, AND C. J. Williams. 2008. Fire effects on rangeland hydrology and erosion in a steep sagebrush-dominated landscape. Hydrological Processes 22:29162929.

Pierson, F. B., P. R. Robichaud, and K. E. Spaeth. 2001. Spatial and temporal effects of wildfire on the hydrology of a steep rangeland watershed. Hydrological Processes 15:2905-2916.

Pierson, F. B., K. E. Spaeth, M. A. Weltz, and D. H. Carlson. 2002. Hydrologic response of diverse western rangelands. Journal of Range Management 55:558-570.

PRISM Group. 2009. United States average monthly or annual precipitation, 1971-2000. Available at: http://www.prismclimate.org. Accessed 19 February 2009

Radcliffe, D. E., E. W. Tollner, W. L. Hardgrove, R. L. Clark, and M. H. Golabi. 1988. Effect of tillage practices on infiltration and soil strength of a typic hapludult soil after ten years. Soil Science Society of America Journal 52:798-804.

RAPER, R. L. 2005. Agricultural traffic impacts on soil. Journal of Terramechanics 42:259-280

Rau, B. M., J. C. Chambers, R. R. Blank, and W. W. Miller. 2005. Hydrologic response of a central Nevada pinyon-juniper woodland to prescribed fire. Rangeland Ecology \& Management 58:614-622.

REEDER, J. 2002. Overcoming spatial variation in measuring soil carbon stocks and sequestration potential of native rangelands in the western U.S. In: C. A. S. Smith [ED.]. OECD expert meeting on soil organic carbon indicators 
for agricultural land. Ottawa, Canada: Agriculture and Agri-Food Canada, Ottawa, Canada; and Paris, France: Organisation for Economic Co-operation and Development. p. 1-11.

Reid, K. D., B. P. Wilcox, D. D. Breshears, and L. MacDonald. 1999. Runoff and erosion in a pinon-juniper woodland: influence of vegetation patches. Soil Science Society of America Journal 63:1869-1879.

Romme, W., C. D. Allen, J. D. Balley, W. L. Baker, B. T. Bestelmeyer, P. M. Brown, K. S. Eisenhart, L. Floyd, D. W. Huffmand, B. F. Jacobs, R. F. Mlller, E. H. Muldavin, T. W. Swetnam, R. J. Tausch, and P. J. Weisberg. 2009. Historical and modern disturbance regimes, stand structures, and landscape dynamics in pinon-juniper vegetation of the western United States. Rangeland Ecology \& Management 62:203-222.

Roundy, B. A., W. H. BLACKBURn, ANd R. E. ECKERT JR. 1978. Influence of prescribed burning on infiltration and sediment production in the pinyon juniper woodland, Nevada. Journal of Range Management 31:250-253.

Roundy, B. A., AND J. L. Vernon. 1999. Watershed values and conditions associated with pinyon-juniper communities. In: S. B. Monsen and R. Stevens [EDS.]. Ecology and management of pinyon-juniper communities in the interior West. Ogden, UT, USA: USDA Forest Service Rocky Mountain Research Station. p. 172-187.

Stringham, T. K., W. C. Krueger, and P. L. Shaver. 2003. State and transition modeling: an ecological process approach. Journal of Range Management 56:106-113.

Sveistrup, T. E., and T. K. Haraldsen. 1997. Effects of soil compaction on root development of perennial grass leys in northern Norway. Grass and Forage Science 52:381-387.

Tausch, R. J., R. F. Miller, B. A. Roundy, and J. C. Chambers. 2009. Piñon and juniper field guide: asking the right questions to select appropriate management actions. Reston, VA, USA: US Geological Survey, Circular 1335. $96 \mathrm{p}$.
United States Department of Agriculture, Natural Resources Conservation Service. 2007. Web soil survey. Available at: http://websoilsurvey.nrcs.usda.gov. Accessed 19 April 2007.

Walker, J. D., M. T. Walter, J. Parlange, C. W. Rose, H. J. T. Meerveld, B. Gao, and A. M. COHEN. 2007. Reduced raindrop-impact driven soil erosion by infiltration. Journal of Hydrology 342:331-335.

Whisenant, S. G. 1999. Repairing damaged wildlands. New York, NY, USA: Cambridge University Press. $312 \mathrm{p}$.

Wilcox, B. P., D. D. Breshears, and C. D. Allen. 2003. Ecohydrology of a resourceconserving semiarid woodland: effects of scale and disturbance. Ecological Monographs 73:223-239.

Wilcox, B. P., D. D. Breshears, and H. J. TuRin. 2003. Hydraulic conductivity in a piñon-juniper woodland: influence of vegetation. Soil Science Society of America Journal 67:1243-1249.

Williamson, R. M., And W. F. Currier. 1971. Applied landscape management in plant control. Journal of Range Management 24:2-6.

Wisdom, M. J., M. M. Rowland, and L. H. Suring. 2005. Habitat threats in the sagebrush ecosystem: methods of regional assessment and applications in the Great Basin. Lawrence, KS, USA: Alliance Communications Group. 301 p.

Wood, M. K., AND N. JAV [EDS.]. 1992. Hydrologic responses to fuel wood harvest and slash disposal on a pinyon-juniper dominated grassland site in the Gila national forest. In: C. T. ORtega-KLett [ED.]. 1992. Proceedings of the 36th Annual New Mexico Water Conference: agencies and science working for the future. Las Cruces, NM, USA: New Mexico Water Resources Research Institute, New Mexico State University. p. 25-30.

ZuzeL, J. F., AND J. J. L. PIKUL. 1993. Effects of straw mulch on runoff and erosion from small agricultural plots in northeastern Oregon. Soil Science 156:111-117. 